\title{
A Woman Traveller in the Moorish Sanctum: A Look at Emily Keene, Shareefa of Wazzan's My Life Story
}

\section{Lahoucine Aammari}

Emily Keene's My Life Story (1911) is a unique travel account as it is written by an Englishwoman, which puts the travelogue in the ambit of female travel narratives. She married a Moorish notable, Sidi Al-Hadj Abd al-Salam, the Shareef of Wazzan, spending, hence, more than four decades amongst the Moors in pre-protectorate Morocco or the "Land of the Furthest West". For more than four decades, Keene managed to live on the cusp of two starkly different cultures, civilizations, religions and societies. Keene was fascinated by the atavistic Moroccan customs and the metaphysical world of the Moors. The man she married epitomized these purely aspired elements. Keene was mesmerized and enchanted by the Moors, their culture and traditions, but at the same time she adhered to her own culture, moving, hence, between two acutely different identities. As an Englishwoman in the Moorish sanctum, Keene was virtually seen by most of the Moors as a Christian from "Bilad al-Nassara" or an "Abode of Disbelief".

\section{Keywords}

Travel Writing; Emily Keene; Shareef of Wazzan; the Moors; Oriental desire; ambivalence; identity

\section{Introduction}

Travel literature is an interdisciplinary genre that, recently, has become an important area of study; it is currently a flourishing literary field: ubiquitous, highly popular, and, most importantly perhaps, unavoidable. It is a characteristically rich source and a vast archive for investigating and exploring many issues and archetypal themes and their inter-relationships. In his introduction to his groundbreaking Culture and Imperialism (1993), Edward W. Said elucidates the intrinsic relationship between culture and empire. 
Said focuses mainly on some metropolitan cultural forms such as novels and travelogues which are quintessentially unquestionable in western culture in the formation of imperial attitudes, references and experiences. He dwells upon how such genres (fictional and otherwise) relentlessly contributed to energizing the myth of empire in the era of full-blown empire, and how some novelists, dramatists, travel writers and painters, etc., regard themselves as the emissaries of civilization as a subterfuge for hegemony and empire. In this vein, travel writing as a discourse is closely intertwined with the signifying practices of imperialist discourse, postcolonialism and many other contested issues besides. According to Julia Kuehn and Paul Smethurst, "'[t]ravel" would henceforth provide a rich source of metaphor in theory-based critical practice. Indeed, it supplied much of the lexicon: displacement, (re-)location, (de-)territorialization, mapping, topology, boundaries, space, place, mobility and so on" (1-2).

Michael Kowaleswski, a pundit and an erudite scholar in the field of travel writing, points out that one of the main features of travel literature lies in its fluidity and openness. He also demonstrates that this genre resists specific, perhaps essentialist, forms of definition on account of its impressively heterogeneous character (43). In the main, travel writing has acquired a new relevance and prestige as a genre that can vociferously proffer important insights into the often fraught encounters and interactions taking place between cultures because most of all journeys and travels are an encounter, and sometimes a confrontation, with what is usually termed alterity; all travel requires us to negotiate a complex and sometimes unsettling interplay between alterity and identity, difference and similarity.

"Travel book" is a very loose generic label, and has always embraced a bewilderingly diverse range of material. This is especially the case as one moves back in time to consider travel writing in its earlier manifestations. Concurrently, and partly as a result of a discursive heterogeneity, travel writing has always sustained a complex and confusing relationship with a number of closely related and often overlapping branches of the humanities and social sciences (Jonathan Raban 253-254). The term can also expose transactions of cultural and political power, helping us thus to demystify imperialism, its aftermath and the effects it wreaked upon weak people and many an issue besides.

In the 1970s and 8os, the burgeoning of scholarly and academic interest in travel writing increased spectacularly; scholars and students working in 
several different disciplines found the genre relevant to a broad gamut of cultural, political and historical debates.

Travel writing and postcolonial studies are common bedfellows. The first is a staple source for the second. Postcolonialism has many aims, the commonest of which is to comprehend and contest the insidious and deleterious consequences of the vast European colonialism of the nineteenth and early twentieth century as an overarching, transhistorical practice, and to decipher and critique travelogues' longer ideological implications and their imperialist undertone (Gregory 9; Campbell 261). Postcolonial critics have thus sought to understand the process that first created, and now perpetuates the inequalities and conflicts between Self and Other, West and Orient, and they have also concerned themselves with intriguing questions germane to how cultures portray each other and how they interact (Thompson 3).

This article is premised upon the analysis of a British woman traveller's, Emily Keene's travel account, My Life Story (1911), travel writing which is interdisciplinary par excellence on the grounds that it brings into focus anthropological, sociological, historical, political, cultural and religious issues. Some of the latter are shed light upon in this article. First, the understanding of the historico-social context under which this travel text was produced is important, and it helps us to lay bare the traveller's background. The way Emily Keene represents her husband, who can be seen as the personification of the Moorish character, the space the Shareefa and Shareef live in as the signifier of the Self and the Other and of identity, her cultural encounters with the Moors, their culture and traditions, and this Other's perspectival gaze towards a Christian woman in the land of Muslims are all issues that are approached in this article.

\section{About Emily Keene, her Marriage and her Account}

Emily Keene, or the Shareefa of Wazzan, paid a visit to Morocco in the 1870 os. Before her marriage, "Emily was the British daughter of John Keene, the governor of Surrey County Prison, and Emma Wharen, who claimed to be the descendant of the archbishop of Canterbury" (Chaouch 276). She sojourned to Morocco in 1872 , at the age of twenty-one, as a governess to the famous American millionaire of Greek origin, Ion Perdicaris, and his wife Ellen. The reasons that prodded her to travel to Morocco indicate that she wanted to 
escape from the stifling Victorian social and cultural values. The traveller tried to avoid and dispose of the atmosphere of ennui and angst which was so predominant in the late nineteenth century or specifically the fin de siècle malaise. Emily Keene, like many travellers of the late nineteenth century, was a belated traveller - though the writer was not a "traveller" in the strict sense of the term - who sought the atavistic, the new and the arcane amongst the Moors, who were perceived as the Oriental other and settled in a far-flung and exotic place reminiscent of that of the Arabian Nights.

Once in Tangier, she drew the attention of a Moroccan notable, the Shareef of Wazzan, who was so infatuated with her manners and beauty that he made every attempt to win her love, leading to a marriage that lasted more than four decades. Emily Keene married the Shareef of Wazzan, the leader of a sanctuary in Wazzan, a sacred city which was regarded as a virtually verboten space for Christians in precolonial Morocco. The word "Shareef" refers to a person whose descent is claimed to be from the Prophet, and it is a denomination which is saturated with esteem and even sanctity. Hence, Emily, a British woman who had herself become part and parcel of a Moorish harem, won the high rank of "Shareefa of Wazzan". It was the outset of a new life in the Moorish Empire that continued more than 70 years. After her husband died in 1892, Emily paid some visits to her homeland, England, where she published her account, My Life Story (1911), recording what she experienced and saw during her stay among the Moors.

When Emily first landed in Tangier, she did not expect at all that her life would be changed upside down when she fell under the allure of the leader of one of the greatest Moroccan lodges in the Morocco of the second half of the nineteenth century. Emily's impression of this notable was imbued with haziness and fascination:

Who, then, was this man who has fascinated me? I used to meet him coming from town, or returning to the mountain, where I was staying with friends, and at length I learnt that it was the Grand Shareef of Wazzan, but that did not convey much to me. I made a closer acquaintance at some musical soirées, which he attended. I certainly thought I liked him, he was so different from the few other Moors I had met. (Emily, Shareefa of Wazzan 4)

The Shareef's marriage was regarded as normal by the other Shareefs (or "Shorfa") of Wazzan because he had already departed from the bosom of 
the Wazzan sanctuary to Tangier after divorcing his wives because of his Christian predilections. The last Shereef had alienated many of his followers. It appears that he imbibed Western ideas, and had contracted the habit of drinking, which the faithful forgave but could not overlook. As a result, he was looked at with suspicion: "The Shareef continued these good offices for some time after his father's death, and on the last occasion he was detained for many months against his will, and became aware of a plot to constitute him a State prisoner, his European predilections being looked upon as dangerous to the welfare of the Empire" (Emily, Shareefa of Wazzan 14). The Shareef's proclivities were accounted by different travellers, envoys and correspondents who journeyed into Morocco at the end of the nineteenth century and who managed to reach the city of Wazzan and meet the Wazzani notable. ${ }^{1}$

At the beginning, Emily refused the marriage on religious grounds, stressing that it "was a difficult matter, and family opposition was strong on all sides" (Emily, Shareefa of Wazzan 1), but in the end she accepted because "life would be impossible without him" (Emily, Shareefa of Wazzan 5). With the presence of her parents and under the eyes of John Drummond Hay, Emily's marriage took place at last under her conditions: the Shareef promised that he would not marry again. In his Morocco as It is. With an Account of Sir Charles Euan Smith's Recent Mission to Fez (1893), Stephen Bonsal, a British traveller and the correspondent of an American newspaper, gives an image of the Shareefa by remarking that Emily was a very intelligent woman. On marrying the Moorish saint, she had the good sense to include in the marriage contract a clause to the effect that if the Shereef should at any time afterwards take to his ample bosom a new wife, he would have to pay her, and again with each repetition of his infidelity, a forfeit of twenty thousand dollars (Bonsal 168).

Also, she had the right to abide by her religion, to live in a coastal town, to proffer her children suitable education, to benefit from her country's protection and to be buried in her homeland, Britain. Besides, she agreed that her children would follow the religion of their father, Islam.

\section{An Englishwoman amongst the Marabouts}

After her marriage, Emily moved to settle in the sanctuary or "Zawiya" wherein she discovered a new life. The Shareef's abode was a shrine for many pilgrims who flocked to be assisted with various troubles and problems. These people regarded the Shareef with awe and respect to the degree of sanctity. It was 
in the sanctuary, where Emily "saw the litigant, the deserted wife, the sick, the barren woman, all seeking consolation by blessings" (Emily, Shareefa of Wazzan 6). Besides, the Shareef of Wazzan was an "homme-fétiche", a fetishman, a healing totem, rather than a political leader.

The Marabouts' sanctum was very strange to Emily at first, but she made up her mind to learn their language in order to understand their culture, way of life and customs. She managed to learn to speak the Tangerine dialect well. Emily Keene had a very different perspective towards the Moorish topos; this unique standpoint can be attributed to the fact that she did not have any colonial enterprise during her settlement in Western Barbary. Quite the contrary, she desired a far-flung space, the Moorish space as an embodiment of something she was shorn of. She sought the atavistic, the fantastic and the mysterious, and she felt that she was able to receive that during her settlement in the sanctuary; she found what she wanted: peace, self-respect, placidity and quietude. This religious brotherhood at the time had great social, cultural and spiritual/religious authority.

Throughout Moroccan history, a sanctuary has been a shrine for a host of people who seek spiritual purification or other aims - at the end of the nineteenth century, for instance, many criminals and those who shunned paying taxes or committed a kind of peculation or embezzlement headed for the sanctuary as a haven against an unbearable dungeon or the cruelty of the local governors or "Qaids". Emily Keene always showed her humanitarian aid to those people who sought a remedy from different ailments because the Moors regarded her as a powerful physician who could purify them from various types of ailments. Indeed, during her stay among the Moroccans, Emily was energetic and active, as she did her best to convince the Moors to cure themselves and acquire medicine from a Christian and proffered them various kinds of help. For Emily, the people considered her quite an authority on their different ailments, particularly those of infants. She received her medical knowledge from many medical men and missionaries that lived in or visited Tangier and other Moroccan cities to spread their medical evangelization. She demonstrated that she was able to increase her little pharmacy, and had the satisfaction that many an infant had possibly had its sufferings assuaged by timely aid. Men and women from all parts flocked to her once it became known she had a medicine chest, and through practice she gained a certain amount of knowledge. With the advent of medical missions, Emily endeavoured to convince the people to patronize them, feeling sure they would obtain much better advice than she could offer them (Emily, Shareefa of Wazzan 74). 
Getting cured by a Christian at the time was a common verboten act among the Moors, for they thought that the purpose of the Christians was to poison and wipe out Muslims: "At first this method was very difficult, and many a bottle of medicine or box of pills was brought to me to assure the owner that it contained no poison, as they had been told that the object of the Christians was to annihilate all Mohammedans" (Emily, Shareefa of Wazzan 74). This kind of suspicion and distrust towards Christians and the latter's detrimental purposes in the "Land of the Moors" reached their pinnacle at the turn of the nineteenth century. As a conspicuous example in this vein is what happened to Dr Émile Mauchamp, a physician, secret agent and amateur ethnographer of the French government, in 1907, who was beaten to death by a Muslim mob in the Moroccan city of Marrakesh. After clubbing him to death and crushing his head, the crowd dragged the naked corpse of Mauchamp by the neck through the city streets on a rope. This gruesome spectacle served as one pretext, among others, for the French invasion of Oujda in 1907 and the establishment of a French protectorate in Morocco in 1912. At his funeral, the French Minister of Foreign Affairs eulogized Mauchamp as "civilization's martyr" to a fanatical Islamic hatred of science.

In this vein, from most of the Moors' standpoint, the Shareef personified the traditional indigenous systems of healing which were predicated upon saintly healing in contradistinction to Emily's practices which were scientific and rational. These Moors looked at her as a Christian whose main purpose was to poison Muslims and taint their healing practices. So, we have a kind of contested binary construct between tradition and modernity, Occident and Orient, nature and culture. Most Moroccan pilgrims looked distrustfully at Emily and they regarded her as a Christian from "Bilad Al-Nasara" or an "Abode of Disbelief". They envisioned her as a person embodying some traits that went against their Shareef's. In this respect, we can posit that these Moroccans considered saintly healing as a social ritual rather than "real" medicine for "real" diseases.

\section{The Shareef of Wazzan: "he was so different from the few other Moors"}

When Emily Keene talks about the Shareef of Wazzan, she does not spare any effort to show her admiration and fascination because simply "he was so different from the few other Moors", and he was very intelligent indeed. 
Regardless of the fact that the Shereef was the leader of a very influential lodge in Morocco of the second half of the nineteenth century, he did not stop manifesting his European predilections and desire for all that was European. Al Hadj Abdesalam's European interests were nothing new; when he was a boy he was constantly criticized by his father because of his "liberal views" and he totally ignored his position as the future "Khalifate" of the sanctuary. When he became the leader of the lodge, he almost left "the House of Surety" (Dar Damana) to settle in Tangier because the latter was seen as the personification of European life. The Shareef was extremely liberal and he did not stop his wife from eating food that was forbidden in Islam; he went with her to do her prayers in the church. Besides, the Shareef was also different because of both the material and spiritual power he possessed: "The position that he occupied was similar to that held by the Popes when they enjoyed the temporal power, but with an added sanctity derived from his descent as a Shareef" (Graham ix).

Most critics who are interested in the history of Moroccan lodges - either Moroccan critics or foreign ones - agree on the idea that one should delve into the main roots by returning back to the movement of mysticism that penetrated Moroccan society starting from the twelfth century. Mysticism had appeared in the Near East as a reaction to the secularized direction Islam had taken over the years. It first appeared as asceticism. By the time it had reached Morocco, it had already begun to produce a number of men (not Shorfa) claiming to have become one with Allah and thus possessing a spiritual power. This was the essence of mysticism. Initially, in both the Near East and Morocco, this Islamic "reformation" was associated with intellectual centres and produced a number of scholarly works on the nature of the world and of God. This mysticism flourished with the downfall of the Watasiyin dynasty, a fact which caused a great transformation in the religious history of this people in favour of a popular mysticism, the main component of which is submission and acquiescence.

Baraka, a kind of blessing or divine power, means a supernatural power facilitating beneficent and miraculous acts. This spiritual power was initially associated with sacred men, "Shorfa". In the succeeding years of Arab decline, Morocco was settled by a number of these sacred men. Most Moroccans would submit themselves to their rule. For many Berbers, even though not completely affected by Islam, the spiritual power possessed by these men was immediately respected. "Compromised" Muslims though they were, Islam was now a part of their culture. They selected those aspects of it which provided 
them with new means for coping with their daily lives. The blessing associated with these sacred men was complementary to honour, and this blessing could be achieved only by the Marabout or the Shareef. This was an attribute which some could obtain without the other: there is the "baraka" of the Marabout and the "baraka" of the Sultan. The lodge contributed directly or otherwise in rooting the main symbolic bases of Makhzen. To borrow Pierre Bourdieu's own words, the symbolic and capital powers the Sultan possessed prodded an array of pretenders, saints and Mahdis to challenge the Sultan for power. The numerous religious brotherhoods were more powerful than the Sultan and were true directors of Muslim souls and sorts of theocratic states. The Sultan of Morocco could not do without the support of the "Shorfa". Some of the latter even gave the sultan a kind of public investiture, like the Shareef of Wazzan himself. ${ }^{2}$

Emily Keene was moving away from the centre and its culture which was a corollary of a civilization that only produced anarchy and philistinism. At the end of the nineteenth century, there was an escape to the fantastic, the imaginative, and, in turn, the non-western. In an article called "Late Victorian to Modernist: 1880-1930", Bernard Bergonzi writes: "In fiction, the fin de siècle mood of withdrawal from everyday reality and the pursuit of a higher world of myth and art and imagination led to a taste for fictional romances" (356). In this manner, the world the traveller reports on will often be foreign, but as Barbara Korte writes in her English Travel Writing from Pilgrimages to Postcolonial Explorations, "the traveller's own country may equally be the object of his or her investigation. Accounts of travel let us participate in acts of (inter) cultural perception and cultural construction, in processes of understanding and misunderstanding" (5).

The representation of the other or the desire for this other is a desire for self-recognition and self-realization on the part of the traveller. The travelling first-person narrator not only looks at those who inhabit the places through which he or she passes, but views them in ways that throw light on his or her own anxieties and desires and of the home culture. Keene moves then to Morocco, a far-flung space that is regarded as a place like the one depicted in the Arabian Nights.

Emily married the Shareef because he was an archetype of spirituality and the purification of the self from all of those taints. He was the spiritual leader that she tried to follow and hold as a model. Also, the house he lived in was very symbolic. She saw that the Shareef was a much respected person among the Moors, for always they came to his abode to seek a kind of blessing for 
whatever problem they had. She saw that people cooperated and helped each other. They were a symbol of solidarity and symbiosis. Emily Keene married the Shareef and she aspired through him to become familiar with those who surrounded him and to get in contact with them. She saw how people came and kissed the Shareef, seeking a kind of remedy for their problems. In his A Visit to Wazzan: The Sacred City of Morocco, Robert Spence Watson succinctly described that ambience when he wrote, "the people waiting there all came forward and kissed the clothes of the Cherif and Cherifa" (67). Keene did her best to utilize that important occasion because via the Shareef's personality she managed to accomplish what she wanted: to be respected by the Moors as the Other. She exemplified this when she rode out for the first time after her marriage, people crowded round the mounting-stone to kiss her husband's hand or garments, pushing by her to do so, whereupon the Shareef said, through his secretary, that whoever ignored Emily must ignore him (Emily Keene 4).

Emily found what she was looking for in her husband. The Moorish notable had a penchant for what was Western and he always showed his predilections for the Europeans way of life. In his travelogue, An Adventure in Morocco, Gerhard Rohlfs, a German traveller who claimed to be the first foreigner to meet the Shareef, was surprised by the notable's Western culture, devoting the sixth chapter of his account to describe him succinctly (Rohlfs 95). In addition to this, the Moorish notable told the traveller that if the occasion was offered to him, he would not spare any effort to Europeanize Morocco: "The Sultan and his grandees, and the doctors of the law", said Sidi, "will not hear of progress and improvement, and for that reason we were beaten by the Spaniards. If only I could do so, I would introduce all the Christians have, or, at all events, a good legislature and a regular army" (Rohlfs 98).

Notwithstanding most of the Moors looked at the notable with suspicion because of his European garb and tendencies, there were some Moroccans who always sought a kind of "baraka": men, women, children, wayfarers, all came and vied with each other to touch their "Sidi", to kiss him on his feet, burnoose or just his horse, to swallow his saliva and to walk in his footprints.

Throughout her travel account, Emily Keene was in support of her husband, and she tried to confirm his European leanings and why he shunned "the House of Surety" in Wazzan after his father's death and preferred to settle in Tangier. He gradually deserted the Court when he perceived it was probable that one day he might find himself constituted a State prisoner on account of his European leanings (Emily Keene 140). The relationship between the 
Shareef and Makhzan grew extremely intense and the idea of assassination obsessed him a great deal. The relationship with the Court exacerbated when the Shareef raised a regiment of his retainers, put them into uniform, and drilled them with the aid of some Spanish prisoners he had at Wazzan. These proceedings caused great commotion at Court, and were assigned to other reasons than mere amusement.

Only later on did the Shareef discover his illusionary project and withdraw the idea completely; "Later on in life the Shareef, yielding to certain propositions made by Europeans, was inclined to entertain the idea of making some attempt to secure secular power, but after mature reflection he rejected the project as impracticable" (Emily, Shareefa of Wazzan 105). The relationship became aggravated between Hassan I and the Shareef. The latter felt that his life was in jeopardy, resorting hence to receiving French protection in 1884 under the aegis of the French Plenipotentiary Ordéga, a fact that enraged the Moorish Sultan and the scholars of Fez, bringing about much enmity for the Shareef. This event irritated the Moroccan Sultan Hassan I (1874-1894). On January 20, 1874, Mohamed Bargash, the Moroccan deputy in Tangier, sent a letter to the British Representative, John Drummond Hay, stating that "[w]e have been informed that Sherif Sidi al-Hadj Abd al-Salam has married an English woman. We must inform you that in so doing the said woman has become Moroccan and her requests can only be judged in the light of Muslim shari'a" (Khalid Ben-Sghir 329).

As a British woman, Emily found herself in a dilemma on the grounds of her husband's becoming a French protégé, as she did not know what the British reaction towards the Shareef's step would be. The Shorfa of Wazzan had strong ties with the British plenipotentiary, John Drummond Hay, since the Hispano-Moroccan Tetouan (1860). Since then, the Shareef of Wazzan had been one of the religious leaders on whom the Makhzan had relied, in coordination with Hay, in solving the problem of the expansion of the borders of Melilla, a Moroccan outpost, occupied by the Spanish, and of assuaging the pressures-cum-threats made by the French against the Makhzan in Moroccan-Algerian borders. His followers were numerous, scattered along a great part of Northern Africa. The Shorfa have, in years gone by, exercised immense influence among their followers, and their presence did more to bring turbulent tribes under subjection than the presence of an army. On this account, they were sought by the Sultans and the French in times of difficulties. It was undoubtedly for the purpose of securing his good offices that the French Government granted him protection. 
In his Memoir, John Drummond Hay states that he received reliable reports that the Shareef of Wazzan wished to arm his followers to confront any attempt by the Makhzan to contain them. In addition to shirking the gouging taxes, the Shareef had also declared that his acceptance of French protection stemmed from his firm conviction that Morocco must become a part of France and that he was prepared to do everything in his power to achieve that end.

\section{Emily's Encounter with an Ambivalent Reality}

Emily made up her mind to marry the Shareef of Wazzan because of his religious position amongst the Moors. She managed to link between two different and acute worlds, that of Christendom and Islam; still, she encountered a reality wherein the indigenous people looked at her with suspicion. Although the people respect her due to her husband's position, they practically regard her as a strange person in their land; Emily was viewed with jaundiced eyes as an outsider as well as an insider. To exemplify, while Emily was taking care of her first baby in the European manner, an old Moorish Wazzani woman who had been in the service of the Shorfa of Wazzan was shocked by the way Emily dressed her new-born baby saying, "Oh, Sidi, Sidi, do come at once; the Christians are killing your son!" (Emily, Shareefa of Wazzan 18).

Emily's husband showed a penchant for what was English and he nursed a strong desire and predilection for Western ways of life and dress. Emily managed to live in a world where there was a strong implicit resistance, and the Moors saw all Christians as a threat to their existence; they adopted an extremist view by thinking that she was there for the sake of corrupting the Shareef, a sacred descendant of the prophet. Emily's stay in Morocco lasted more than forty years and she adapted herself to the different and almost unusual circumstances around her.

Emily was truly faced by two acutely different stark realities. She was immersed in the world of the Moors, their culture and religion on the one hand, but on the other, she found it difficult to adapt herself to certain mores because of the misgivings that some Moors harboured towards her. In his introduction to Emily's account, Samuel Levy Bensusan claims that

On one side were the Moors, naturally jealous at the entrance of a foreigner into the native life. Upon the other were the Europeans, all striving to enlist her husband on their side, for in those days the French were working by 
degrees towards that position in Morocco which they have since attained. (ix)

\section{Keene's Movement between Two Identities}

Emily viewed Moorish clothes as a form of cultural resistance to her Europeanness, a mode of self-fashioning through which she constituted her desired image: the other mesmerized in herself. For Ali Behdad, the belated Orientalism of travellers like Emily Keene vacillates between "an insatiable search for a counter-experience in the Orient and the melancholic discovery of its impossibility; they are, as a result, discursively diffracted and ideologically split" (Behdad 15). Her shift between donning English clothes and Moorish ones is evocative of her unstable and unsteady search for a wholly unified identity and personality in a stifling Victorian context. The clothes she dresses in are of paramount importance; they are not only an embodiment of identity, but they are also a desire to be the other; her masquerade in Moorish clothes is significant as she strips herself of the British identity, albeit ephemerally, to achieve her desire as an Englishwoman who searched for the exotic and the fantastic.

Clothes are the conspicuous signs of social and cultural identity; they also personify the symbolic power that the Shareef claims to possess. Hence, attiring oneself in Moorish garb poses the problem of identity for the traveller; to wear Moorish clothes is both a way of renouncing one's identity and a form of conversion to the other's imaginary. More than a dialectic, Emily's relation to mimesis and alterity, identification and difference, is an unremitting movement between these two terms. Identification is simultaneously alienating and confrontational as Homi Bhabha puts it. To deal with this threat, the subject can adopt the Other's identity through which she can accomplish several aims and tasks. Put otherwise, by donning Moorish dress, which she highly enjoys, Keene crosses cultural bridges, violates national barriers, and denies difference by becoming artificially Other. Unlike many other British travellers who crossed the Strait, journeyed into Barbary as a virtually verboten space and clad themselves in Moorish clothes for strategic reasons, Emily Keene possessed a strong longing to be like the Other, a longing which can be rendered as "a desire for the Orient", to use Ali Behdad's phrase (14). ${ }^{3} \mathrm{Her}$ relationship with the Moors includes involvement and indulgence, a kind of giving of oneself over to the experience of the Oriental journey. For Emily, 
an understanding of the other could be attained and achieved only through "immersion", a whole-hearted participation in the Other and its culture: "Continual daily visits from one or the other were rather inconvenient, as they came at all hours, so I suggested that every Friday I would be at home. I felt rather strange in my European dress, so I decided to have some native costumes for these occasions" (Emily, Shareefa of Wazzan 91).

The desire for the Orient, as Behdad points out, is "a hybrid force that posits uncertainty in the Orientalist's consciousness and enables possibilities of dialogic articulation because it propagates different identity effects and ideological positions" (30). We can say that Emily settled on the cusp of two different cultures, and she engaged, therefore, in a kind of self-parody and self-irony as a strategy of self-protection and self-presentation. For Mary Louise Pratt, the European relations with the Other are characterized by parody and self-parody. These European relations with the Other are governed by a desire for reciprocity and exchange; estrangement and repulsion are represented as completely mutual and equally irrational on both sides. This discourse does not explicitly seek a unified, authoritative speaking subject. The subject here is split simply by virtue of relating itself as both protagonist and narrator, and it tends to split itself even further. The self sees, it sees itself seeing, it sees itself being seen, and always it parodies itself/and the Other (Pratt 105).

After spending about twenty-five years among the Moors and after her husband's demise, Emily made the decision to revisit her motherland, England. She felt that something was missing and that she was a stranger in a strange land; people looked different to her, rushing hither and thither for dear life's sake, absorbed in the material life of the West which was far removed from that of the Orient. Thus, for a few days she "felt a stranger in a strange land" (Emily, Shareefa of Wazzan 287). After a holiday of three months, she returned with far different impressions of her native land, than she had hitherto treasured up. Her impressions were pleasant in a way, but she could not eradicate the feeling that something was missing. Still, Keene wrote that she managed to surmount all the difficulty of living on the borderline of two different cultures:

I suppose I expected to take up the thread of existence where I left it, which naturally was an impossibility in every sense of the word, but the impression remained all the same. Neither did I realise until this journey how different my mode of life is to the generality of Europeans, yet I have preserved to an extraordinary extent the manners and customs habitual 
to an Englishwoman, and I have trained numbers to respect them, so that many of the natives do to the best of their ability. I still try to meet them as far as it is possible in their manners and customs, and in all the years I have lived in Morocco, we have never clashed, so deferential are they to my wishes. (289)

At the end of her account, as a last word, Keene wrote that she did not advise anyone to follow in her footsteps, but at the same time she demonstrated that she had not a single regret, and she hoped that her forty years of residence among the Moors could have some benign influence on the future. Emily Keene died in Tangier in 1943.

\section{Conclusion}

Emily Keene's travel account is a paradigmatic illustration and product of the meeting between two cultures. Emily headed towards the "Land of the Sunset" at the turn of the nineteenth century. She felt that there was something absent which she tried to fill, and it was precisely this primordial absence that motivated the subject's quest for Oriental paradise, the search for a beyond that always lay somewhere she was not. Her husband, a Shareef and a Marabout, was the epitome of otherness that mesmerized her during her stay amongst the Moors for more than four decades. Some of the Moroccan pilgrims, whose shrine was the Shareef's, looked at Emily with distrust because they saw in her a Christian woman whose main purpose was either to taint their relationship with their saintly man, whose Western proclivities had grown substantially, or to vie with them, and to possess the Shareef's divine power. Still, during her stay among the Moroccans, Keene managed to live on the edge of two different cultures and identities, succeeding virtually in building bridges between the East and the West. Her constant and eager search for the fascinating strange, the pristine and the atavistic, and something outside the common British modes of life, prodded her to become artificially Other with an adherence to her own culture. 


\section{Notes}

1. As examples of these travellers and envoys, we can mention, inter alia, Arthur Leared, Stephen Bonsal, Walter Harris, Lawrence Harris, Robert Spence Watson, John Drummond Hay, Philip Durham Trotter, Robert Cunninghame Grahame, Budgett Meakin and Donald Mackenzie.

2. The notes about the original roots of religious sanctuaries in Morocco and their function that I subsume within this section are not for the sake of historicity, but rather to shed some lights upon the patchy relations that existed between the leaders of some lodges and the central government (the Makhzan = the Sultan). Because of his "strange" tendencies, the Shareef of Wazzan was looked at with suspicion and distrust.

3. A desire for the Orient (Le désir de l'Orient) is an expression firstly used by the French traveller, Gérard de Nerval, in his travel book Voyage en Orient. 2 vols. Paris: Garnier Flammaration, 1980.

\section{Works Cited}

Arata, Stephen. Fictions of Loss in the Victorian Fin de Siècle. Cambridge: Cambridge University Press, 1996. Print.

Ashcroft, Bill. Postcolonial Transformation. London: Routledge, 2001. Print.

Behdad, Ali. Belated Travellers: Orientalism in the Age of Colonial Dissolution.

Durham, NC and London: Duke University Press, 1994. Print.

Ben-Sghir, Khalid. Britain and Morocco during the Embassy of John Drummond Hay, 1845-1886. Trans. Malcolm Williams and Gavin Waterson. London: Routledge Curzon, 2005. Print.

Bergonzi, Bernard. "Late Victorian to Modernist: 1880-193o." In An Outline of English Literature. Ed. Pat Rogers. Oxford: Oxford University Press, 1998: pp. 347-391. Print.

Bhabha, Homi. The Location of Culture. London: Routledge, 1994. Print.

Bongie, Chris. Exotic Memories: Literature, Colonialism and the Fin de Siècle. Stanford: Stanford UP, 1991. Print.

Bourdieu, Pierre. Language and Symbolic Power. Trans. Gino Raymond and Matthew Adamson. Cambridge: Polity Press, 1993. Print.

Bourqia, Rahma. Adawla wa Sulta wa Lmoujtamaa. Beirut: Dar Taliaa, 1991. Print.

Brooks, L.A.E. A Memoir of Sir Fohn Drummond Hay: Sometime the Minister at the Court of Morocco Based on His fournal and Correspondence. London: John Murray Albemarle Street, 1896. Print.

Campbell, Mary Baine. The Witness and the Other World: Exotic European Travel Writing 400-1600. London: Cornell University Press, 1980. Print. 
Chaouch, Khalid. "When East Meets West in Emily Keene's My Life Story (1911)." In Middle Ground: Fournal of Literary and Cultural Encounters, issue 5 (2013): pp. 277-296. Print.

Emily, Shareefa of Wazzan. My Life Story. Ed. Samuel Levy Bensusan. (Third Impression). London: Edward Arnold, 1912. Print.

Graham, R.B. Cunninghame. "Preface." My Life Story. Ed. Bensusan Samauel Levy. London: Edward Arnold, 1912.

Gregory, Derek. Geographical Imaginations. Oxford: Blackwell, 1994. Print.

Hagopian, Elaine C. "The Status and Role of the Marabout in Pre-Protectorate Morocco." Ethnology, Vol. 3, No. 1 (Jan., 1964). Print.

Hulme, Peter and Tim Youngs, eds. The Cambridge Companion to Travel Writing. Cambridge: Cambridge UP, 2002. Print.

Korte, Barbara. English Travel Writing from Pilgrimages to Postcolonial Explorations. Trans. C. Matthias. Houndmills: Palgrave, 2000. Print.

Kowaleswski, Michael, ed. Temperamental fourneys: Essays on the Modern Literature of Travel. Athens: University of Georgia Press, 1992. Print.

Kuehen, Julia and Paul Smethurst, eds. New Directions in Travel Writing Studies. London: Palgrave Macmillan, 2015. Print.

---. eds. Travel Writing, Form, and Empire: The Poetics and Politics of Mobility. London: Routledge, 2009. Print.

Parry, Benita. Postcolonial Studies: A Materialist Critique. London: Routledge, 2004. Print.

Pratt, Marry Louis. Imperial Eyes: Travel Writing and Transculturation. London: Routledge, 1992. Print.

Raban, Jonathan. For Love \& Money: Writing - Reading - Travelling 1968-1987. London: Picador, 1988. Print.

Rohlfs, G.F. Adventures in Morocco and Fourneys through the Oases of Draa and Tafilelt. London: S. Low, Marston, Low, \& Searl, 1874. (Available online $<$ http:/www.archive.org./details/adventuresinmorolrohlgoog>)

Said, Edward. Orientalism: Western Conceptions of the Orient. London: Routledge, 1978. Print.

---. Culture and Imperialism. London: Vintage Books, 1993. Print.

Spurr, David. The Rhetoric of Empire: Colonial Discourse in Travel Writing and Imperial Administration. London: Duke UP, 1993. Print.

Thompson, Carl. Travel Writing. London: Routledge, 2011. Print.

Watson, Robert Spence. A Visit to Wazzan: The Sacred City of Morocco. London: Macmillan and Co., 188o. Print. 


\section{Acknowledgements}

I owe a debt of gratitude to my supervisor, Dr Moulay Lmustapha Mamaoui, for his unstinting remarks and constructive feedback. Many thanks also to Dr Khalid Chaouch for his encouragement.

LAHOUCINE AAMMARI is a teacher and PhD candidate, working on British travellers' accounts of Morocco (1860-1945). He is currently affiliated with Interactions in Literature, Culture and Society, University of Sultan Moulay Slimane, Béni-Mellal, Morocco. His primary academic research interests are focused on the novel, cultural studies, colonial discourse analysis, postcolonial theory and the travel narrative. He is the author of a book entitled The Image of Morocco in British Travel Accounts.

ammarielho@gmail.com 